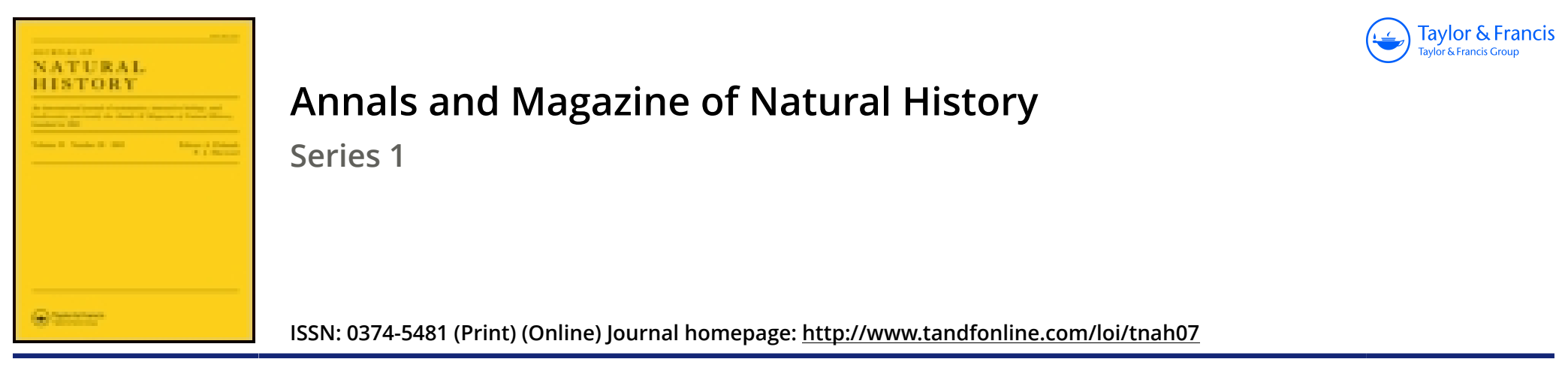

\title{
XXIV.-Descriptions of some newly discovered species of Araneidea
}

\section{John Blackwall Esq., F.L.S.}

To cite this article: John Blackwall Esq., F.L.S. (1844) XXIV.-Descriptions of some newly discovered species of Araneidea, Annals and Magazine of Natural History, 13:83, 179-188, DOI: 10.1080/03745484409442591

To link to this article: http://dx.doi.org/10.1080/03745484409442591

$$
\text { 曲 Published online: } 04 \text { Dec } 2009 .
$$

Submit your article to this journal $₫$

LII Article views: 1

Q View related articles $₫$

Citing articles: 2 View citing articles 
mensions of the Benral bird, according to Dr. Pearson, are, length 6 in. by $\mathrm{l} l$ in. in alar expanse, and the wing measures $3 \frac{3}{7}$ in., the stuffed specimen showing it to be searcely smaller than Tringa platyrhyncha. I would therefore provisionally style it Eu. orientalis.

Nov. 17th.-Terchia jaranica continues to be brought to the bazar, one or two erery morning; also Tringa platyrhyncha, or Limicola pygmea of Nilsson; and I obtained a third specimen of the Kentish plorer this morning, together with a lot of Glareola orientalis.

I hercin inclose skins of Culicipeta Burkii, Philloscopus reguloides, Ph. modestus, two, Ph. affinis and Ph.lugubris, which kindly sllow to Mr. Gould and Mr. G. R. Gray, and ask their opinion of them. I request Mr. Gray's acceptance of them for the British Museum, but will send him better and mounted specimens by and by. I cannot delay this note for the departure of the express, as the specimens make it too bulky to be then received; but if auything should turn up in the meanwhile worthy of being recorded I will let you know.

Believe me ever, very truly yours,

H. Britrir.

XXIV.-Descriptions of some newly discovered species of Arancidea. By Jomn Blackwald, Esq., F.L,S.

Tribe OCTONOCULINA.

Family AGEI.ENID \&.

Genus Tegenaria, Walck.

1. Tegenaria sceva. Cephalo-thorace paliide flavescenti-brunueo; linea tenui mediana antice, fascia lata, irregulari longitudinali, ad utrumque latus marginibusque lateralibus obscure brunneis ; mandibulis saturnte fusco-brunneis; maxillis labroque rufescenti-brunneis; sterno fascia mediana rufescenti-brunnea, postice gradatim tenuiure, et ad latera fascia lata semilunari saturate brunnea puncta varia rotunda rufescenti-brunnca pedum versus insertionem includenti ; pedibus longis, pilosis rufescenti-brunneis nisi ad femorn $2^{\mathrm{di}}$ $3^{\text {til }} 4^{\text {ti }}$ que ubi color obscure viridescenti-brunneus; coxis subtus maculis plurimis nigris, pedum pari $4^{\text {to }}$ longissimo, dein $1^{\text {mo }}, 3^{\text {tio }}$ brevissimo; lineis medianis ad partem abdominis superiorem angulatis favescenti-brunneis, ad filatoria brevioribus et obscurioribus, quarum vertices prorsum spectantes prope seriei anteriorem partem fascia Iongitudinali fusco-lutea intercepti; extremitates autem valde dilatatx maculis nigris irregularibus alternantes; lateribus fusco-luteis dense nigro-maculatis; abdomine subtus medio flavescenti-brunneo, inter strigas duas obscurns, e maculis plurimis nigris conprositas, ad filatoria junctas. 
Mas famina minor, pallidior, maculis fascileque obscuriuribus : maris par pedum primum $4^{\text {to }}$ longius.

Length of the female, not including the spinners, $\frac{7}{10}$ ths of an inch; length of the cephalo-thorax $\frac{5}{16}$; breadth 7.5 ; breadth of the abdomen $\frac{1}{6}$; length of a posterior leg $1 \frac{1}{5}$; length of a leg of the third pair 1.

The anterior part of the cephalo-thorax is compressed, and the posterior part is marked with furrows diverging from a narrow indentation in the medial line to the lateral margins, which are rounded; it is thickly covered with hairs, and is palc yellowish brown, with a fine line extending along the middle of the anterior part, a broad, itrecrular, longitudinal band on each side, and lateral marrins of a dark brown colour. Eyes alınost equal in size, disposed ill two transverse rows on the anterior part of the cephalo-thorax; the anterior row is rather the shorter and nearly straight; the posterior row is curved and has its convexity directed backwards; the intermediate cyes of both rows form a square nearly, the anterior ones being rather the largest of the eight ; the cyes of each lateral pair are scated obliquely on a small eminence, but are not contiguous. Mandibles powerful, conical, vertical, provided with two rows of tecth and some long liairs on the inner surface; they are of a dark reddish brown colour approaching to black. Maxilla straight, increasing in brcadth from the basc to the extremity, which is rounded on the outer side, and obliquely truncated aud supplied with long hairs on the inner side : lip quadrilateral, longer than broad, slightly notched at the apex: these parts are reddish brown, the lip being the darkest, and are palest at their extrenities. Sternum heart-shaped, with a red-brown band extending along the middle, which decreases in breadth to its posterior extremity, and a large dark brown scmilunar band on each side, comprising several circular red-brown spots opposite to the insertion of the legs. Legs long, hairy and reddish brown, with the exception of the thighs of the second, third and fourth pairs, which are of a dull greenish brown colour; sereral black spots occur on the under side of each haunch; fourth pair the longest, then the first, third pair the shortest. Each tarsus is terminated by threc claws; the two superior ones are curved and pectinated, and the inferior one is intlected near its basc, which is furnished with several fine teeth. Palpi dark reddish bromn, with a curred pectinated claw at the extremity. $\Lambda \mathrm{b}$ domen oviform, hairy, convex above, projecting over the base of the cephalo-thorax; along the middle of the upper part extends a series of yellowish brown angular lines, which become shorter and less conspicuous as they approach the spinners; their vertices, which are directed forwards, are interrupted at the anterior part of the series by a longitudinal band of yellowish brown, and with 
their extrenities, which are greatly enlarged, black blotches of an irregular figure alternate; the sides are yellowish brown thickly spotted with black; the middle of the under part, which is yellowish brown, is comprised between two obscure bands, composed of nunerous black spots, which meet at the spimners. The superior spimers are long, hairy, triarticulate, and have the spinning tubes disposed on the under side of the terminal joint, which tapers to its extremity and is reddish brown; the second joint is black. Plates of the spiracles dull yellow. This species and some others of the same family, Tegenaria domestica, Tegcnaria civilis, and Agelena labyrinthica, for example, have the body and limbs supplied with numcrous compound sessile hairs. Similar hairs occur also on Dolomedes mirabilis, belonging to the Lycosida.

The male is smaller, slenderer, paler, and less distinctly marked than the female, and the relative length of its Iegs is different, the first pair being longer than the fourth; their absolute length also is greater, an anterior one measuring 1 inch and $\frac{1}{2} \frac{g}{u}$ ths. The palpi are yellowish brown, with the exception of the radial and digital joints, which are reddish brown; the radial joint is longer than the cubital and has tro apophyses at its extremity; one large; black and obtuse, situated on the outer side, the other smaller, red-brown and acute, situated ou the under sicle; the dimital joint is of an elongated pyriform figure pointed at the extremity ; it is convex and hairy extermally, concare within, at the upper part only, comprising the palpal organs, which are moderately developed, prominent, rather complicated in structure, with a strong, black, pointed process projecting boldly from the upper part, a prominent scaly process at the inner side of the upper part, and a long, slender, curved black spine originating near the extremity on the inner side, and directed obliquely uprards towards the outer side; their colour is red-brown.

Living specimens of Tegenaria sata, which ranks among our largest British spiders, were obligingly presented to me in the autumn of 1843 by Miss Gertrude Buller Elphinstone, of East Lodge, Inficld, Middlesex, who captured then in the immediate neighbourhood in which she resides. In reply to some inquiries relative to the habits of this fine species, Miss Lilphinstone informs me that it frequents the interior of buildings; and $I$ have ascertained, from observations made on individuals in a state of captivity, that it constructs a horizontal sheet of web of a compact texture, with a short tube at one of its margins scring the spider for a retreat.

Baron Walckenaer, in the Supplement to the second rolume of his 'Iistoire Naturelle des Insectes Aptères,' p. 407, ascribes to M. Dugès the discovery of the true structure and function of the elongated superior spinners of certain - spiders denominated anal 
palpi by arachnologists, referring at the same time to the original observations of M. Dugès on the subject, published in the "Annales des Sciences Naturclles,' 1836, seconde séric, t. vi. Zoologic, p. 166. When the paragraph comprising the statenent of this opinion was penned, MI. Walchenaer doubtless was not aware that a paper of mine, iucluding a correction of the crroncous impression that the superior pair of spinners when considerably elongated and pointed at the extremity perform the office of feclers merely, and distinctly detailing the particulars of thcir cxtcrnal organization and use, was published in the 'IReport of the Third Mecting of the British Association for the Advancement of Science, held at Cambridge in 1833,' p. 4.5; and republished in 1834 in my 'Researches in Zoology', pp. 298-300. Additional evidence of the accuracy of the conclusions here referred to is afforded by the structure of the superior spinners of Tegenaria saca.

\section{Family THERIDIIDE.}

\section{Genus Neriëise, Blackw.}

2. Neriëne favipes. Mas niger, pedibus sordide luteis; pedum pari $1^{\text {mo }}$ et $4^{\text {to }}$ longissimis, aqualibus, $3^{\text {to }}$ brevissimo.

Length of the male $\frac{1}{1} g^{t h}$ of an inch; length of the cephalo-thorax $\frac{1}{25} ;$ breadth $\frac{1}{32}$; breadth of the abdomen $\frac{1}{32}$; length of an anterior leg $\frac{1}{8}$; length of a leg of the third pair $\frac{1}{10}$.

Cephalo-thorax oral, glossy, conrex, with a slight indentation in the medial line of the posterior region: mandibles powerful, conical, divergent at the extremitics, armed with a few minute tecth on the inner surface, and inclined towards the stermum, which is convex and heart-shaped: maxilla strong, enlarged where the palpi are inscrted, and inclined towards the lip, which is semicircular and prominent at the extremity : abdomen oviform, sparingly corercd with hairs, convex above, projecting over the base of the cephalo-thorax : all these parts are black. The intermediate eyes form a trapezoid whose anterior side is rather the shortest; the posterior eyes of the trapezoid are the largest, and the anterior ones the smallest of the eight. Legs of a dull yellowish hue; first and fourth pairs the longest and equal in length, third pair the shortest. 'This spider, like the rest of the genus, has the tarsi terminated by three claws; the two superior ones arc curved and pectinated, and the inferior one is inflected near its base. Palpi black, with a tinge of brown; the cubital and radial joints are short, the latter being much the larger; the digital joint is somewhat oval, with a bold conical prominence in front, and a small one at the upper part on the inner side; it is convex and hairy extermally, concave within, comprising the palpal 
Mr. J. Blackwall on some new spacies of Arancidea.

organs, which are highly developed, complicated in structure, and of a dark reddish brown colour.

This species was taken on rails at Oakland in February 1841.

3. Ncriēne timida. Cephnlo-thorace, mandibulis, maxillis, labio, sternoque saturate fusco-brunneis; pedibus palpisque pallide rufescenti-brunneis, abdomine nigro; pedum pari $1^{\text {mo }}$ et $4^{\text {to }}$ longissimis, xqualibus, $3^{\text {tio }}$ brevissimo.

Quoad colorem pedumque longitudinem mas fominæ similis.

Length of the female $i^{1}$ th of an inch; length of the cephalo. thorax $\frac{1}{2}$; breadth $\frac{1}{32}$; breadth of the abdomen $\frac{1}{2} \frac{1}{5} ;$ length of an anterior leg $\frac{1}{3}$; length of a leg of the third pair $\frac{1}{T} \bar{z}$.

Cephalo-thorax oval, glossy, conver, with the sides depressed, and a small indentation in the medial line of the posterior region: mandibles powerful, conical, rather divergent at the extremities, armed with tecth on the inner surface, and inclined towards the sternum, which is broad and heart-shaped: maxilla strong, enlarged where the palpi are inserted and at the extremity, and inclined towards the lip, which is semicircular and prominent at the apex: these parts are rery dark brown. The intermediate cyes form a trapezoid, the anterior ones of which are the smallest of the eight. Lers and palpi palc reddish brown. First and fourth pairs of legs the longest and equal in length, third pair the shortest. Abdomen oviform, convex above, projecting orer the base of the cephalo-thorax; it is thinly clad with hairs, glossy and black. Plates of the spiracles dark brown.

The male is rather smaller than the female, but resenubles her in colour and in the relative length of its legs. The cubital and radial joints of the palpi are short, the latter being much the stronger; the digital joint is oval, convex and hairy externally, concave within, comprising the palpal organs, which are moderately developed, complicated in structure, with a short prominent spine enveloped in a transparent niembranc at their extremity, and are of a dark reddish brown colour.

Mature males and females of this species were found on rails at Oakland in April 18+1.

4. Ncrï̈ne saxatilis. Mas cephalo-thorace, mandibulis, maxillis, labio, sterno, pedibus, palpisque brunneis, sterno labioque saturatioribus, pedibus pallidioribus; abdomine nigro-fusco; pedum pari $1^{\text {mo }}$ et $4^{\text {to }}$ equalibus, longissimis, $3^{\text {tio }}$ brevissimo.

I ength of the male ${ }_{1}^{1}$ th of an inch; length of the cephalo-thorax $\frac{1}{25}$; breadth $\frac{1}{28} ;$ breadth of the abdomen $\frac{1}{28} ;$ length of an anterior leg $\frac{1}{7}$; length of a leg of the third pair $\frac{1}{10}$.

The tro intermediate pairs of eyes form a trapczoid whose anterior side is rather the shortest. Cephalo-thorax oval, glossy, 
$184 \mathrm{Mr}$. J. Blackwall on some new species of Arancidca.

convex, with an indentation in the medial line of the posterior region : mandibles strong, conical, armed with tecth on the inner surface, and inclined towards the sternum, which is heart-shaped : maxillix inclined towards the lip, which is semicircular and prominent at the extremity : first and fourth pairs of legs the longest and cqual in length, third pair the shortest : these parts, with the palpi, are brown, the sternum and lip being the darkest, and the legs much the lighest coloured. The radial joint of the palpi is much larger than the cubital, and projects from its extremity, in front, a pointed apophysis which is curved ontwards; the digital joint is somewhat oval, with a bold protuberance at the upper part, which is deeply indented on the outer side; it is convex and hairy externally, concave within, comprising the palpal organs; they are highly developed, complicated in structure, and of a reddish brown colour. Abdomen oviform, convex above, projecting over the base of the cephalo-thorax; it is thinly covered with hairs, glossy and brownish black. Plates of the spiracles brown.

In June 1811 this spider was captured among fragments of rock in a wood near Hendre Housc.

5. Neriëne sulcata. Mas forea para longitudinali pone oculorum par utrumque laterale; cephalo-thorace, mandibulis, maxillis, labio, sternoque nigro-fuscis, mandibulis et maxillis sub-rufescentibus, his pallidioribus; pedibus palpisque rufis, fuscoque tinctis; abdomine nigro-fusco; pedum pari $1^{\text {mo }}$ paullo longrori, dein $4^{\text {to }}$, $3^{\text {tho }}$ brevissimo; oculis serici anterioris intermediis cateris multo minoribus.

Length of the male $T_{T}^{1}$ th of an inch; length of the cephalo-thorax $\frac{1}{24}$; breadth $\frac{1}{28}$; breadth of the abdomen $\frac{1}{28}$; length of an anterior leg $\frac{1}{8}$; length of a leg of the third pair $\frac{1}{1} \frac{2}{2}$.

The legs and palpi are provided with hairs, and are red with a tinge of brown. First pair of legs rather the longest, then the fourth, third pair the shortest. Ccphalo-thorax oval, glossy, convex, with a small longitudinal indentation inmediately behind cach latcral pair of eyes, and a slight depression in the me: dial line of the posterior region: mandibles powerful, conical, conrex in front, near the base, divergent at the extremities, armed with tecth on the inner surface, and inclined towards the sternum, which is broad and heart-shaped: maxille strong, enlarged where the palpi are inserted, and inclined towards the lip, which is semicircular and prominent at the extremity: thesc parts are brown-black, the maxilla, which are the palest, and the mandibles having a tinge of red. Anterior eyes of the trapezoid much the smallest of the eight; eyes of each lateral pair contiguous and seated on a prominence. The cubital and radial 
joints of the palpi are short, the latter, which is the stronger, projecting a pointed apophysis from its extremity, in front; the digital joint is somerihat oval, with a lobe near the middle of the outer side; it is convex and hairy extcrnally, concave within, comprising the palpal organs, which are highly dercloped, proninent, complicated in structure, with a loug, black, filiform, convoluted spine, enveloped in a delicate membrane, extending from the upper part beyond their extremity; they are of a redbrom coloul. Abdomen oriform, conver above, projecting over the base of the cephalo-thorax; it is thinly corcred with hairs, glossy, and brownish black. Plates of the spiracles jellow.

My son, Jolm Blackwall, discorered an adult male of this species, which is nearly allicd to the spiders constituting the genus Walckenaëra, on the steps at Oakland in June 184.1.

6. Neriëne avida. Oculis seriei anterioris intermediis minimis; cephalo-thorace, mandibulis, maxillis, labio, sternoque brunneis, pedibus palpisque pallidioribus; mandibulis, maxillis et labii apice paululum rufo-tinctis; abdomine fusco-nigro; pedum pari $1^{\text {mo }}$ ct $4^{\text {to }}$ longissimis, æqualibus, $3^{\text {to }}$ brevissimo.

Colore pedumque longitudine mas fæminam refert; cephalo-thoracis pars anterior gibbosior, et pone oculos duabus lateralibus parra fovea.

Length of the female $\frac{1}{1}$ th of an inch; length of the cephalo-tho$\operatorname{rax} \frac{1}{2} \pi$; breadth $\frac{1}{2} \frac{1}{2}$; breadth of the abdomen $\frac{1}{25}$; length of an anterior leg $\frac{1}{3}$; length of a leg of the third pair $\frac{1}{12}$.

Legs and palpi provided with hairs; first and fourth pairs of legs the longest, and equal in length, third pair the shortest: cephalo-thorax oval, glossy, convex, with a small indentation in the medial line of the posterior region: nandibles powerful, conical, rather divergent at the extremities, armed with teeth on the inner surface, and inclined towards the stcrmum, which is broad and lieart-shaped: maxille strong, enlarged where the palpi are inserted, and inclincel towards the lip, which is semicircular and prominent at the extremity : these parts are brown, the legs and palpi, which are the palest, the mandibles, maxillæe, and tip of the lip having a tinge of red. Anterior eyes of the trapezoid the smallest of the eight; eyes of each lateral pair scated on a prominence and almost contiguous. Abdomen oviform, convex above, projecting over the base of the cephalo-thorax; it is thinly covered with hairs, glossy, and brownish black. Plates of the spiracles yellowish brown.

The male is rather smaller than the female, but it resembles her in colour and in the relative length of its legs. The anterior part of the cephalo-thorax is more gibbous, and immediately behind each lateral pair of eyes there is a small indentation. The 
radial joint of the palpi, which is larger than the cubital, projects a pointed apophysis from its cxtremity, in front ; the digital joint is somewhat oval, the supcrior part, which is slender, being curved outwards, aud a lobe occurring on the onter side, near the middle; it is convex and hairy externally, concave within, comprising the palpal organs, which are highly dereloped, prominent, complicated in structure, with a bold projection near the upper part, on the inner side, and a long, black, convoluted, filiform spine, cnreloped in a delicate membrane, extending from the upper part beyond their extremity; they are of a reddish brown colour.

Males and females of Neriene acida in a state of maturity were captured on rails at Oakland in $A$ pril 1839. A close affinity subsists between this species and Neriëne sulcata, which form the link connecting Neriëne with Walckenä́ra, and show by how easy a transition the one genus passes into the other.

\section{Farnily EPFïRID A. \\ Genus EPEÏra, Walck.}

7. Epeïra similis. Maris cephalo-thorace flavescenti-brunneo, fascia nimrescenti mediana in anteriori parte dilatata; mandibulis fuscorufis; maxillis liabioque rufescenti-brunneis, apicibus flarescentibrunneis, ad labri basin saturatioribus; sterno fusco-nigro fascia mediana longitudinali flavescenti-brunneo postice angustiore. Pedibus flavescenti-brunneis nigro-maculatis, pari $1^{\text {mo }}$ longissimo, dein $2^{\text {do }}, 3^{\text {to }}$ brevissimo, palpis brevibus fusco-luteis articulo digitali rufo-brunneo, articulis cubitalibus radialibusque brevibus, his paululum majoribus. Ablominis superiori parte macula lata ovali phylloidea fusco-grisea, apice anteriori lineis flexuosis transversis ad filatoria gradatim in longitudine decrescentium argenteo-griseis; marginibus angulatis nigris, antice utrinque macula ovali brumnea; vitta attenuata argenteo-grisea margini nigra parallela lateribus subtusque fuscis luteo-tinctis punctis nigris minimis interspersis, infra fascia lata mediana nigra utrinque striga lutea.

Length of the male $\frac{1}{5}$ th of an inch; length of the cephalo-thorax $\frac{1}{10}$; breadth $\frac{1}{12} ;$ breadth of the abdomen $\frac{1}{11}$; length of an anterior $\log \frac{7}{1} z$; length of a leg of the third pair $\frac{1}{4}$.

Eyes disposed in two transverse rows on the anterior part of the ecphalo-thorax; the intermediate ones of both rows form a square, the two anterior ones, which are seated on a small protuberance, being the largest of the eight; the cyes constituting cach lateral pair are placed obliquely on a prominence, and, though near togrether, are not in contact. Cephalo-thorax somewhat oval, compressed before, rounded in front, convex, glossy, with an indentation in the medial line of the posterior region; it is of a yellowish brown colour, with a blackish band, which is broadest at its anterior extremity, extending along the micldle. Man- 
dibles powerful, conical, rertical, armed with tecth on the inner. surface; they are of a red-brown colour. Maxille short, strong, straight, and broad at the extremity, which is rounded : lip nearly semicircular, but somewhat pointed at the apex: these parts are reddish brown, with yellowish brown extremities, the base of the lip being much the darkest. Sternum heart-shaped, with small protuberances on its sides opposite to the articulation of the legs; it is brownish black, with a longitudinal band of yellowish brown in the middle, which diminishes in breadth to its posterior extremity. Legs long, provided with hairs and black spines; they. are yellowish brown spotted with black; first pair the longest, then the second, third pair the shortest. Palpi short and yellowish brown, with the exception of the digital joint which is red-brown; the cubital and radial joints are short; the latter is rather the larger and is provided with some long hairs; the digital joint is short, oval, convex and hairy externally, concave within, comprising the palpal organs, which are moderatcly devcloped, prominent, complicated in structure, with a curved black spine at their extremity directed upwarls, a projecting process at the upper part, towards the inner side, and are of a dark red-brown colour. $\Lambda$ bdomen sparingly clad with hairs, oviform, somewhat depressed, projecting over the base of the cephalo-thorax; on the upper part is a large, oval, leaf-shaped figure of a bromnish gray colour comprising a longitudinal row of small, black, slightly indented spots on each side of the medial line; the anterior part of the leaf-shaped mark and a series of curved transverse lines, diminishing in length as they approach the spinners, are silvergray; its margins are festooned and black, and an oval brown spot occurs on each side of its anterior extremity; following the undulations of the black border is a narrow band of silver-gray; sides and under part brownish with a tinge of yellow and minute blackish spots interspersed; a broad black band extends along the middle of the under part, on each side of which is a stripe of yellow. Plates of the spiracles yellow.

The spider from which the foregoing description was made was discovered at East Lodge, Enfield, by Miss Gertrude Buller Elphinstone, to whom I am indebted for it and for numerous interesting species of Arachnida and Insecta; indeed, the liberality of Miss Elphinstone in transmitting to me specimens of living spiders collected by her in Middlesex demands the tribute of my grateful acknowledgments.

At present I am aequainted with the male only of Epeïra similis, which bears so close a resemblance to the male of Epeïra calophylla as scarcely to be distinguished from it except by the palpi and palpal organs. By way of contrast, I shall bricfly point out some of the more remarkable particulars in which the latter dif- 
fers from the former. Its palpi are long and red-brown, with a black annulus at the base of the cubital and radial joints; the cubital joint gradually increases in bulk to its extremity and is curved downwards, and the radial, which greatly exceeds it in length, projects a minute bifid apophysis from its extremity; on the outer side; the palpal organs have a prominent bifid process at their upper part, on the inner side, and a long, slender, curved, black spine at their extremity, which is dirceted upwards.

A collection of liring spiders sent to me in Scptember 1843 from Ellesmere, in Shropslire, by Miss Margarct B. Lewis, of Cichle, Anglescy, contained a young male Epcïra similis, which, as the digital joints of its palpi were rery tumid, had to undergo its final change of integument before it arrived at maturity. On comparing this individual with males of Epeira calophylla in the same state, I perceived that its palpi were much shorter, and that the protuberance at the upper part of the under side of the digital joint was decidedly smaller than in the latter species. The sides of the cephalo-thorar in the specimen receired from Miss Lewis were finely bordered with black.

XXV._Obserrations on a now species of dinanthc. By the Rev. W. II. Colmaras, MI.A., F.B.S.*

[With a Plate.]

UNder the name of Enanthe Phellandrium, two clistinct forms have long been confounded. The first, which is the Phellandrium aquaticum of Yinnæus, and the Einarithe Phellandrium of Smith and others, is figured in 'E. B.' (t.684); the other, though frequent in the rivers of the south-east of England, has hitherto becn much overlooked; not being noticed even as a varicty in any work to which $I$ have access, except by Dillenius in his edition of 'Ray's Synopsis,' until I drew the attention of MIr. C. C. Babington to it. It is noticed in that gentleman's 'Minual of British Botany' (p. 131), under the name of E. I'hellandrium $\beta$ fluciatilis; and I now venture to propose it as a distiuct species, with the titlc of $\alpha$. fluriatilis, offering the following characters for it and its ally :-

1. Enanthe Phellandrium ("Lamk."); caule erecto deorsum incras. sato, fibris ad genicula verticillatis; foliis tripinnatis, segmentis simplicibus pinnatifidisve, submersorum capillaceis, superiorum divaricatis; umbellis oppositifoliis; fructu ovato stylis suberectis duplo longiore. Biennis. Habitat in aquis stagnantibus.

2. Enanthe furiatilis; caule fluitante sursum incrassato basi repente ad genicula radicante; foliis bipinnatis, segmentis simplicibus pinnatifidisve, submersorum pellucidis cuneatis fissis, nervis plu-

- Read before the Botanical Society at Edinburgh, 1lth Jnn. 1814. 